\title{
Predictors of Stunting Among Children Under Five Year of Age in Indonesia: A Scoping Review
}

\author{
Henny Suzana Mediani ${ }^{1}$ \\ ${ }^{1}$ Departement of Pediatric Nursing, Faculty of Nursing, Universitas Padjadjaran, Bandung, Indonesia \\ Correspondence: Henny Suzana Mediani, Faculty of Nursing, Universitas Padjadjaran, Bandung, Indonesia. Tel: \\ 62-822-1739-1965. E-mail: henny.mediani@unpad.ac.id
}

Received: March 9, 2020 Accepted: April 26, 2020 Online Published: June 8, 2020

doi:10.5539/gjhs.v12n8p83 URL: https://doi.org/10.5539/gjhs.v12n8p83

\begin{abstract}
The cases of stunting in Indonesian children under five years of age is become national issues. This is due to the prevalence of stunting in Indonesian children has still remained high comparing to other southeast countries, at the national level is approximately $31 \%$. The consequences of child stunting may give both immediate and long term and include increased morbidity and affect to child growth and development. There is evidence of some factors are known as risk factors of stunting in children globally. The aim of this review is to identify the current literature and compile the predictors that have been associated with stunting in Indonesia and where data gaps remain. A systematic search of the literature between 2010 and 2018 was conducted using PubMed, Google Scholar, Scopus, EBSCO and Clinical Key. A search of the literature was performed by using keywords: stunting, determinants, children under five year of age, factors, Indonesia. Papers were included in this review if they identify an association between child stunting and exposure to determinant factors. The author selected 18 articles in the final analysis that met with the criteria. The included studies indicated that there are several main predictors of child stunting: child factors (low birth weight, premature birth); maternal factors (parental short stature, parental education); infection, and breast feeding. A diverse range of contributing factors are, to varying degrees, associated with stunting, demonstrating the importance of considering how those predictors interacts with nutrition. Integrated health promotion, prevention and interventions by health care providers, communities including health cadres is needed to prevent new stunting children in Indonesia
\end{abstract}

Keywords: Children under five years, determinant factors, Indonesia, predictor, stunting.

\section{Introduction}

A golden age period of childhood is an important period in growth due to at this time the basic growth of child that will influence and determine the next development of the child (UNICEF., 2014). One of the nutritional problems that are often faced by young children is stunting that adversely impact of the quality of life of children in achieving optimal growth according to their genetic potential (WHO., 2010). Childhood stunting is still a serious health problem globally, particularly in low income countries and developing countries (UNICEF., 2014; WHO., 2012). It is predicted around 155 million children under five years of age had stunting globally, among whom, $36 \%$ were residing in African countries and 27\% in Asian countries (UNICEF., 2014). Stunting in children under five year of age denotes poor linear growth during a critical period and is diagnosed as a height for age less than -2 standard deviations from the World Health Organization (WHO) child growth standards median (WHO., 2012). In line with stunting, wasting is also identified as a public health threat in Southern Asia, including Indonesia (Black et al., 2014; the Global Nutrition Report., 2017).

Indonesia is one of the developing countries that has a high prevalence of stunting, from 88 countries in the world, and Indonesia is at the top five of stunting cases (UNICEF., 2014). Stunting remains a major public health problem in Indonesia. It is approximately $37.8 \%$ of Indonesian children were reported to be stunted in 2015, while in 2018 the prevalence of child stunting decreased to reach 31\% (National Institute of Health Research and Development., 2018). Although in Indonesia has been reducing the prevalence of stunting with annual average reduction rate of $7.3 \%$ during 2013 to 2018 , the progress is still quite low compared to WHO standardize (National Institute of Health Research and Development., 2018). It is alarming due to the declining childhood stunting was not satisfactory and inadequate. So that way, the issue of stunting in childhood is now become a government priority.

Stunting during childhood can result in negative health effects across the lifespan, including high morbidity and 
mortality such as life-threatening complications during birthing, increased infant mortality rates, reduced cognitive performance and development, increased risk of infections, poor, delayed psychomotor development, lower school performance, poor intelligent quotients (IQ), emergence of chronic diseases, reduced production capacity in adulthood, with loses in economic growth and social developement of the country (Strewart et al., 2013; Black et al., 2014; Beal et al., 2017).

The World Health Organization has a Global Nutrition Targets for reducing the number of stunting children under five years old by $40 \%$ in 2025 and a key indicator in the second Sustainable Development Goal of Zero Hunger (WHO., 2012). The most important time to meet a child's nutritional requirement is in the first 1,000 days which is from conception to the child of 2 years of age (Black et al., 2013). During the first 1,000 days, the child needs adequate nutrition to support growth and development of the child (Black et al., 2013; WHO., 2012). After the age of two years the rate of growth slows down, and the child is considered stunted. Existing literature notices that stunting result from a complex interaction of a number of determinant factors such as house hold and family factors: poor nutrition during pre-conception, prenatal and lactation, short maternal stature, infection, intrauterine growth rate (IUGR) and preterm birth; inadequate complementary feeding, breasfeeding, water and sanitation, socio economic and cultural influences as stated in conceptual framework of stunting by the World Health Organization that cause of stunted growth (Stewart et al., 2013).

Over the past decade in Indonesia, there has been little change in the national prevalence of child stunting as mentioned previously. There are large disparities subnational, ranging by province from $26 \%$ in Riau Islands to $52 \%$ in East Nusa Tenggara (Torlesse et al., 2016). This indicates the variation in the population's exposure to determinants of child stunting and the need to target and tailor interventions to the most vulnerable. Literature notes that there are numerous potential risk factors of child stunting in Indonesia, including proximate factors such as maternal nutritional status, breastfeeding practices, complementary feeding practices, and exposure to infection as well as related distal determinants such as education, food systems, health care, water and sanitation infrastructure and services. The purpose of this article is to review the current evidence to determine what has been studied and can be concluded as the determinants of childhood stunting in Indonesia. In this review the author uses the WHO child stunting framework (Stewart et al., 2013) to organize studies with an outcome of under five child stunting or linear growth into the appropriate determinant categories (Figure 1).

Stunted growth and development

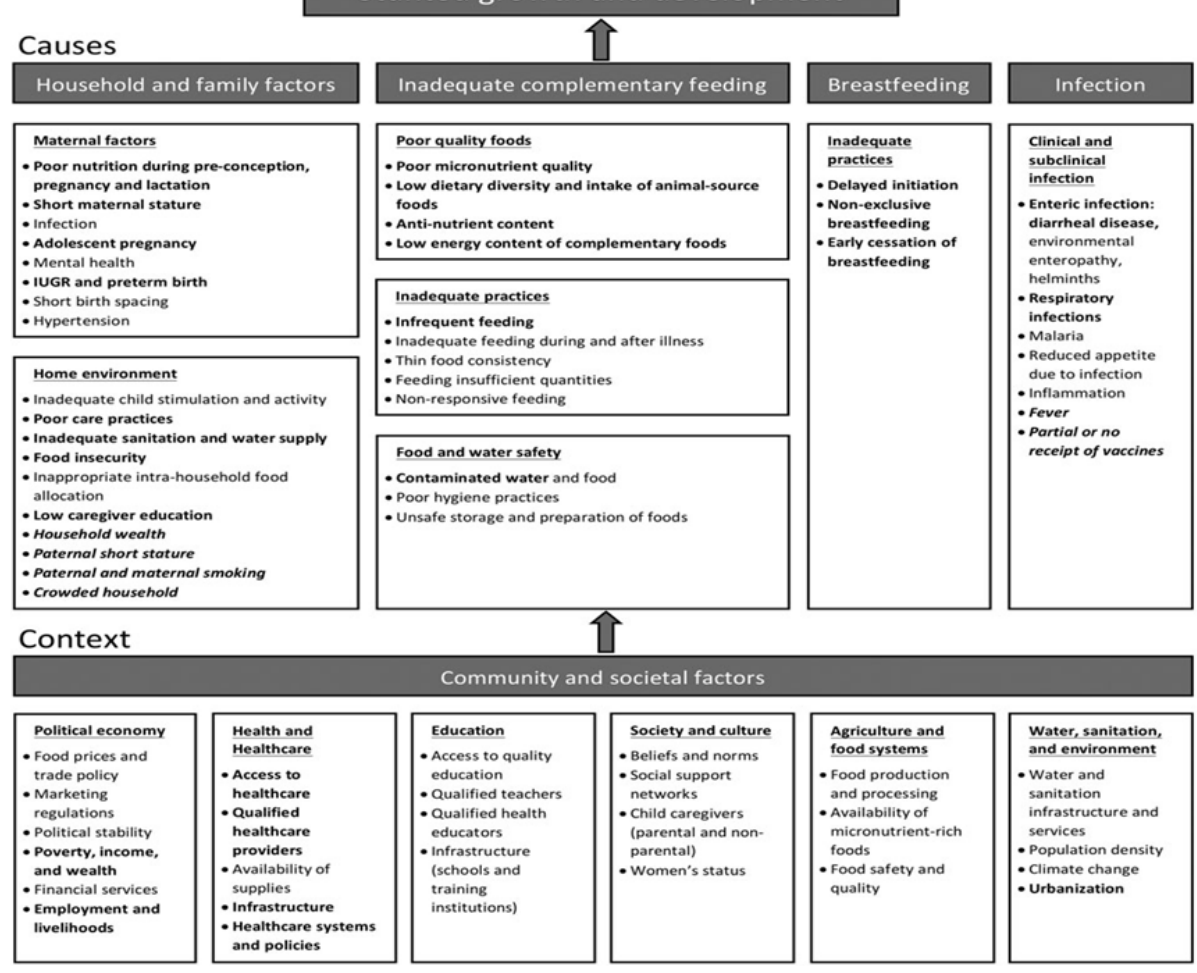

Figure 1. The World Health Organization conceptual framework on childhood stunting: Proximate causes and contextual risk factors. 


\section{Method}

The preparation of the systematic scoping review of literature consists of several stages including:

\subsection{Making Research Questions}

Before starting the literature review, the author formulated the objectives of the literature review study first and formulated research questions to guide the search of literature. The research question developed is what are the predicting factors that associate to the incidence of stunting in children under five year of age?

\subsection{Looking for Data Sources and Literature Search Strategy}

After developing research questions, the next step is to search for journal articles published through electronic databases. The search strategy is reported below. A systematic search of the literature between 2010 and 2018 was performed using data from PubMed, PMC, Google Scholar, Proquest, Scopus, EBSCO, Web of Science and Clinical Key. In examining child stunting determinants worldwide, we used keyword searches in data based such as PubMed Central (PMC), Google Scholars, and Web of Science. For PMC, PubMed, the author used the term "malnutrition [All Fields] AND ("growth disorder" [MeSH Terms] OR ("Child stunting" [All Fields]). For Google Scholar and Web of Science, the author used the keywords "stunting, households, parenting, factors, determinants, predicting". Papers were included in this review if they identify an association between child stunting and exposure to predictor factors.

\subsection{Inclusion/Exclusion Criteria}

Studies were eligible if they met the following criteria:

1. Study site: Studies conducted in Indonesia.

2. Design: Randomized and non-randomized controlled trial (RCTs), Cross sectional, Survey and observational studies

3. Outcome: Stunting in children under five years of age.

4. Relevance: Studies published in English and Bahasa Indonesia that addressed any causal or contextual factors of stunting as identified in the WHO framework.

\subsection{Studies Selection}

The total titles/abstracts identified in the database werre17.727, and no additional titles/abstracts through additional searching outside of the databases. After excluding duplicated titles/abstract, remained 606 and after a further removal of $505(83.3 \%)$ duplicated titles/abstract, obtained 101 titles/abstract. In the next stage, the full text articles were examined in more depth. For the remaining 101 articles screened, 59 were excluded because were not studies conducted in Indonesia, 24 outcomes did not meet the inclusion criteria, it was only 18 studies which met the criteria. This review focused on risk factors that can contributed to stunting in children under five years of age in Indonesia. All studies included were appraised for minimizing risk of bias. The selection process is illustrated in Figure 2 below. 


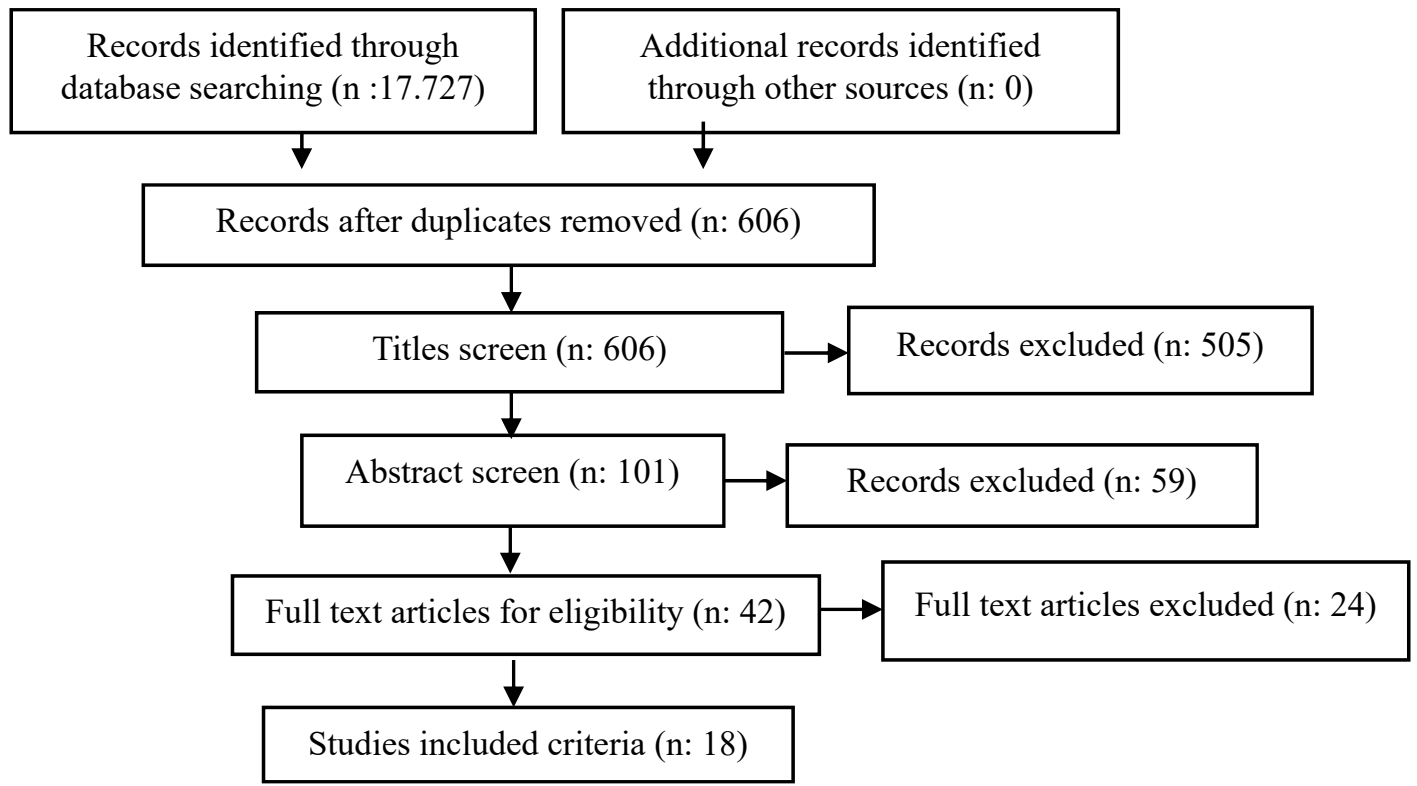

Figure 2. Flow of studies through the selection process

\section{Results}

Based on the results of the screening of 18 articles selected from 2010-2018, all articles were analyzed using quantitative methods, with a cross sectional and case control research design. Table 3 present summary of review literature. In the research results, there are 3 main risk factors or predictors that associated to child stunting in Indonesia follow the WHO framework of stunting: 1) household and family factors, 2) infection and 3) breastfeeding.

Table 3. summary of review literature

\begin{tabular}{|c|c|c|c|c|c|}
\hline Authors & $\begin{array}{l}\text { Objective } \\
\text { study }\end{array}$ & Subject & Design & Place & Findings \\
\hline $\begin{array}{lr}\text { Inochi } & \text { Lara } \\
\text { Palino, } & \text { Ruslan } \\
\text { Majid, } & \& \\
\text { Ainurafiq } & (2017)\end{array}$ & $\begin{array}{l}\text { To know Risk } \\
\text { factors of } \\
\text { stunting in } \\
\text { children under } \\
\text { five years of } \\
\text { age }\end{array}$ & $\begin{array}{l}65 \text { cases and } 65 \\
\text { controls } \\
\text { (children under } \\
\text { five years of } \\
\text { age) }\end{array}$ & $\begin{array}{l}\text { Case control with } \\
\text { matching } \\
\text { procedure }\end{array}$ & $\begin{array}{l}\text { Puuwatu Health } \\
\text { Center, Kendari } \\
\text { City Indonesia }\end{array}$ & 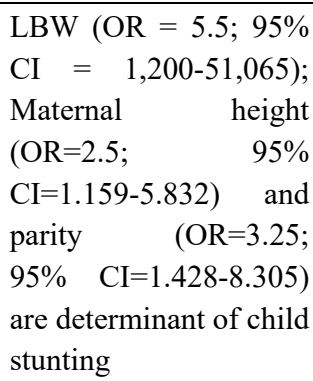 \\
\hline $\begin{array}{l}\text { Murtini } \\
\text { Jamaluddin } \\
(2018)\end{array}$ & $\begin{array}{l}\text { To identify the } \\
\text { factors } \\
\text { associated } \\
\text { with the } \\
\text { incidence of } \\
\text { stunting in } \\
\text { children aged } \\
0-36 \text { months }\end{array}$ & $\begin{array}{l}25 \text { stunting } \\
\text { children under } \\
\text { three year of } \\
\text { age }\end{array}$ & sectional & $\begin{array}{l}\text { Lawawoi Public } \\
\text { Health Center, } \\
\text { Sidenreng } \\
\text { Rappang } \\
\text { Regency } \\
\text { Indonesia }\end{array}$ & $\begin{array}{l}\text { There is a relationship } \\
\text { between LBW with } \\
\text { stunting with a value of } \\
\mathrm{p}=0.008(\mathrm{p}<\alpha=0.05\end{array}$ \\
\hline $\begin{array}{l}\text { Ninna Romawati } \\
\text { \& Ruli Bahyu } \\
\text { Antika (2014) }\end{array}$ & $\begin{array}{l}\text { To know risk } \\
\text { factors } \\
\text { associated } \\
\text { with the } \\
\text { incidence of }\end{array}$ & $\begin{array}{l}120 \text { stunting } \\
\text { children under } \\
\text { three year of } \\
\text { age }\end{array}$ & $\begin{array}{l}\text { cross-sectional } \\
\text { design }\end{array}$ & $\begin{array}{l}\text { District of } \\
\text { Jember East Java } \\
\text { Indonesia }\end{array}$ & $\begin{array}{l}\text { Low parent education, } \\
\text { low parent income, } \\
\text { parenting, lower } \\
\text { education and income } \\
\text { family, parenting and }\end{array}$ \\
\hline
\end{tabular}


stunting

among

children aged

6-36 months poor diet, and not given

exclusive breast milk,

never suffered an

infection,

Low birth weight

$<2500 \mathrm{~g}(\mathrm{p}=0,000 ;$ OR

$=4,192 ; 95 \% \mathrm{CI}=$

$1,900-9,247)$ and low

To analyze risk

factors of

stunting in

children aged

360 children cross sectional

study

Bogor West jva paternal education at

Province $\quad<12$ years $(\mathrm{p}=0,035$;

Indonesia $\quad \mathrm{OR}=1,807$;

$95 \% \mathrm{CI}=1,042-3,133)$.

is a risk factor for stunting in children of 6-24 months

\begin{tabular}{|c|c|c|c|c|c|}
\hline $\begin{array}{l}\text { Cut Novianti } \\
\text { Rachmi, } \\
\text { Kingsley } \\
\text { Agho, Louise } \\
\text { Alison Bau \& } \\
\text { Yanqiao Zhang, } \\
\text { Edito (2016) }\end{array}$ & $\begin{array}{l}\text { To: a) } \\
\text { determine } \\
\text { temporal } \\
\text { trends in the } \\
\text { prevalence of } \\
\text { underweight, } \\
\text { stunting, and } \\
\text { at risk of } \\
\text { overweight/ } \\
\text { overweight or } \\
\text { obesity in } \\
\text { Indonesian } \\
\text { children aged } \\
2.0-4.9 \text { years; } \\
\text { and b) } \\
\text { examine } \\
\text { associated risk } \\
\text { factors. }\end{array}$ & $\begin{array}{l}22,000 \\
\text { children } \\
\text { stunting }\end{array}$ & Survey & $\begin{array}{l}\text { Sumatra, Java, } \\
\text { Kalimantan and } \\
\text { Sulawesi Island } \\
\text { Indonesia }\end{array}$ & $\begin{array}{l}\text { There is strong } \\
\text { associations between } \\
\text { stunting and a lower } \\
\text { birth } \\
\text { underweight children, } \\
\text { and mothers' and } \\
\text { fathers' education } \\
\text { levels. }\end{array}$ \\
\hline $\begin{array}{l}\text { Erna } \\
\text { Kusumawati, } \\
\text { Setiyowati } \\
\text { Rahardjo, and } \\
\text { Hesti Permata } \\
\text { Sari (2015) }\end{array}$ & $\begin{array}{l}\text { To analyze risk } \\
\text { factors related } \\
\text { to child, } \\
\text { mother, and } \\
\text { environment } \\
\text { factors for } \\
\text { stunting under } \\
\text { three years in } \\
\text { order to } \\
\text { develop a } \\
\text { control model }\end{array}$ & $\begin{array}{l}\text { Case sample is } \\
50 \text { stunting } \\
\text { toddlers, the } \\
\text { control sample } \\
\text { is } 50 \text { normal } \\
\text { status toddlers }\end{array}$ & $\begin{array}{l}\text { Observational } \\
\text { with case control }\end{array}$ & $\begin{array}{l}\text { The working area } \\
\text { of the } \\
\text { Kedungbanteng } \\
\text { Health Center, } \\
\text { Banyumas } \\
\text { Regency } \\
\text { Indonesia }\end{array}$ & $\begin{array}{l}\text { The risk factor for } \\
\text { stunting and being the } \\
\text { most dominant factor is } \\
\text { infectious disease }\end{array}$ \\
\hline $\begin{array}{l}\text { Dicka Indo Putri } \\
\text { Priyono, } \\
\text { Sulistiyani,and } \\
\text { Leersia Yusi } \\
\text { Ratnawati (2015) }\end{array}$ & $\begin{array}{l}\text { To analyze the } \\
\text { determinant of } \\
\text { stunting in } \\
\text { children aged } \\
12-36 \text { months }\end{array}$ & $\begin{array}{l}86 \quad \text { children } \\
\text { under five were } \\
\text { taken by simple } \\
\text { random } \\
\text { sampling } \\
\text { technique }\end{array}$ & Cross sectional & $\begin{array}{l}\text { Randuagung } \\
\text { Public Health } \\
\text { Center, } \\
\text { Lumajang } \\
\text { Regency } \\
\text { Indonesia }\end{array}$ & $\begin{array}{l}\text { There is a relationship } \\
\text { between infectious } \\
\text { diseases, and genetics } \\
\text { with the incidence of } \\
\text { stunting. } \\
\text { Genetic is the most } \\
\text { influential risk factor } \\
\text { for stunting }\end{array}$ \\
\hline
\end{tabular}


To identify the relationship between stunting and nongrain food expenditure at

Sari et al. (2010) the household level among children $0-59$ mo old in Indonesia's rural and urban poor population.

5 urban poor populations from slum areas in the cities of Padang, Jakarta,

Semarang, Surabaya, and Makassar and the rural population

Forty thousand households were selected
The Nutrition and Health Surveillance System (NSS) from

provinces of

West Sumatra, Lampung,

Banten, West Java, Central Java, East Java, the island of Lombok (West Nusatenggara), and South Sulawesi.

\begin{tabular}{|c|c|c|c|c|c|}
\hline $\begin{array}{l}\text { Friska Meilyasari } \\
\text { et al. (2014) }\end{array}$ & $\begin{array}{l}\text { To Identify } \\
\text { risk factors of } \\
\text { children } \\
\text { stunting under } \\
3 \text { year of age }\end{array}$ & $\begin{array}{l}24 \text { toddlers for } \\
\text { cases group and } \\
24 \text { toddlers for } \\
\text { control group }\end{array}$ & Case control & Kendal Indonesia & $\begin{array}{l}\text { The risk factors of } \\
\text { stunting in toddlers are } \\
\text { prematuritas, }\end{array}$ \\
\hline $\begin{array}{l}\text { Aryastami et al. } \\
(2017)\end{array}$ & $\begin{array}{l}\text { To analyze the } \\
\text { relationship } \\
\text { between low } \\
\text { birth weight } \\
\text { (LBW), child } \\
\text { feeding } \\
\text { practices and } \\
\text { neonatal } \\
\text { illness with } \\
\text { stunting } \\
\text { among } \\
\text { Indonesian } \\
\text { toddlers. }\end{array}$ & 3,368 infants & $\begin{array}{l}\text { Cross sectional } \\
\text { study }\end{array}$ & $\begin{array}{l}33 \text { provinces and } \\
441 \text { districts in } \\
\text { Indonesia }\end{array}$ & $\begin{array}{l}\text { LBW is the major } \\
\text { determinant of stunting } \\
\text { in children }\end{array}$ \\
\hline $\begin{array}{l}\text { Anna Vipta Resti } \\
\text { Mauludyani, Umi } \\
\text { Fahmida \& Otte } \\
\text { Santika (2012) }\end{array}$ & $\begin{array}{l}\text { To know risk } \\
\text { factors } \\
\text { associated } \\
\text { with the } \\
\text { incidence of } \\
\text { stunting } \\
\text { among } \\
\text { children aged } \\
6-36 \text { months }\end{array}$ & $\begin{array}{l}31569 \text { children } \\
\text { under five year } \\
\text { of age }\end{array}$ & $\begin{array}{l}\text { The ecological } \\
\text { study (survey) }\end{array}$ & $\begin{array}{l}437 \text { districts in } \\
33 \text { provinces in } \\
\text { Indonesia }\end{array}$ & $\begin{array}{l}\text { Prevalence of high } \\
\text { stunting was associated } \\
\text { with income, } \\
\text { proportion of low } \\
\text { education of mother } \\
\text { and proportion of food } \\
\text { expenditure. }\end{array}$ \\
\hline $\begin{array}{l}\text { Isnninda Priska } \\
\text { Syabandini, Siti } \\
\text { Fatimah } \\
\text { Pradigdo, } \\
\text { Suyatno, Dina } \\
\text { Rahayuning }\end{array}$ & $\begin{array}{l}\text { To analyze risk } \\
\text { factors for } \\
\text { stunting in } \\
\text { children aged } \\
6-24 \text { months } \\
\text { in fishing areas }\end{array}$ & $\begin{array}{l}60 \text { respondents } \\
\text { consisting of } 30 \\
\text { cases and } 30 \\
\text { controls }\end{array}$ & $\begin{array}{l}\text { Observational } \\
\text { research using } \\
\text { quantitative } \\
\text { research } \\
\text { methods, } \\
\text { descriptive } \\
\text { analytic types and }\end{array}$ & $\begin{array}{lr}\text { Tambak } & \text { Lorok } \\
\text { Village, Tanjung } \\
\text { Mas Village, } \\
\text { North Semarang } \\
\text { Indonesia }\end{array}$ & $\begin{array}{l}\text { Children who have Low } \\
\text { Birth Weight (LBW) } \\
\text { are a 19-fold greater } \\
\text { risk factor for stunting } \\
\text { compared to children } \\
\text { who have normal birth }\end{array}$ \\
\hline
\end{tabular}




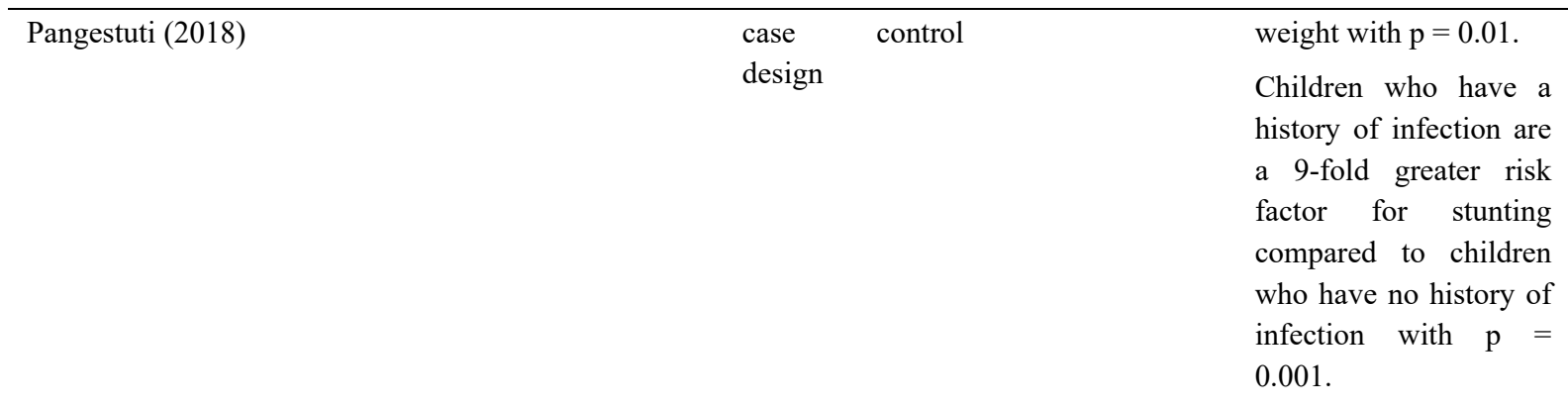

\begin{tabular}{|c|c|c|c|c|c|}
\hline $\begin{array}{l}\text { Endi } \\
\text { Prawirohartono, } \\
\text { Detti Nurdiati, \& } \\
\text { Moammad } \\
\text { Hakimi (2016) }\end{array}$ & $\begin{array}{l}\text { To estimate the } \\
\text { inluence of } \\
\text { prognostic } \\
\text { factors } \\
\text { detected at } \\
\text { birth for } \\
\text { stunting at } 24 \\
\text { months of age } \\
\text { and the } \\
\text { occurennce of } \\
\text { reversal of } \\
\text { stunting at } 24 \\
\text { months of age } \\
\text { among } \\
\text { children in a } \\
\text { rural area of } \\
\text { Indonesia. }\end{array}$ & 343 infants & $\begin{array}{l}\text { A randomized } \\
\text { controlled, } \\
\text { double-blind, } \\
\text { community-based } \\
\text { study }\end{array}$ & $\begin{array}{l}\text { a rural area of } \\
\text { Indonesia. }\end{array}$ & $\begin{array}{l}\text { Boys who were born } \\
\text { prematurely with low } \\
\text { birth weight and } \\
\text { small-for-gestational } \\
\text { age have significantly } \\
\text { higher risk to become } \\
\text { stunted at } 24 \text { months of } \\
\text { age. }\end{array}$ \\
\hline $\begin{array}{l}\text { Khoirun Ni'mah, } \\
\& \text { Siti Rahayu } \\
\text { Nadhiroh (2015) }\end{array}$ & $\begin{array}{l}\text { To determine } \\
\text { factors } \\
\text { associated to } \\
\text { stunting } \\
\text { among } \\
\text { children under } \\
\text { five }\end{array}$ & $\begin{array}{l}35 \text { children } \\
\text { under five year } \\
\text { of age for cases } \\
\text { and } 35 \text { children } \\
\text { under five year } \\
\text { of age for } \\
\text { control }\end{array}$ & Case control & $\begin{array}{l}\text { Distric Surabaya } \\
\text { Indonesia }\end{array}$ & $\begin{array}{l}\text { There was a } \\
\text { relationship between } \\
\text { birth length, exclusive } \\
\text { breastfeeding, family } \\
\text { income, mother's } \\
\text { education and mother's } \\
\text { nutrition knowledge of } \\
\text { stunting among } \\
\text { children under five year } \\
\text { of age }\end{array}$ \\
\hline $\begin{array}{l}\text { Manggala et al. } \\
(2018)\end{array}$ & $\begin{array}{l}\text { To investigate } \\
\text { the risk factors } \\
\text { of stunting in } \\
\text { children aged } \\
24-59 \text { month }\end{array}$ & 166 children & Cross sectional & $\begin{array}{l}\text { Gianyar Bali, } \\
\text { Indonesia }\end{array}$ & $\begin{array}{l}\text { Risk factors for stunting } \\
\text { in children are low } \\
\text { paternal education, } \\
\text { maternal height less } \\
\text { than } 150 \mathrm{~cm} \text {, high risk } \\
\text { maternal age, low birth } \\
\text { weight, low birth length } \\
\text { and unexlusive } \\
\text { breastfeeding. }\end{array}$ \\
\hline $\begin{array}{l}\text { Zilda } \text { Oktarina \& } \\
\text { Trini } \quad \text { Sudiarti } \\
(2014)\end{array}$ & $\begin{array}{l}\text { To analyze risk } \\
\text { factors of } \\
\text { stunting in } \\
\text { underfive } \\
\text { children aged } \\
24-59 \text { months } \\
\text { in Sumatera. }\end{array}$ & 1,238 children & Cross sectional & $\begin{array}{l}\text { Aceh, North } \\
\text { Sumatera, South } \\
\text { Sumatera, and } \\
\text { Lampung } \\
\text { Provinces }\end{array}$ & $\begin{array}{l}\text { The significant risk } \\
\text { factors of stunting } \\
\text { among subjects } \\
(\mathrm{p}<0.05) \text { were mother's } \\
\text { height }(\mathrm{OR}=1.36) \text {, fat } \\
\text { intake }(\mathrm{OR}=1.30) \text {, } \\
\text { family size }(\mathrm{OR}=1.38) \text {, } \\
\text { and drinking water } \\
\text { resources }(\mathrm{OR}=1.36) .\end{array}$ \\
\hline
\end{tabular}


The dominant factor

that associated with

stunting in children was

family size $(\mathrm{OR}=1.38)$.

\begin{tabular}{|c|c|c|c|c|c|}
\hline $\begin{array}{l}\text { Indriani et al. } \\
(2018)\end{array}$ & $\begin{array}{l}\text { To analyze } \\
\text { prenatal } \\
\text { factors } \\
\text { associated } \\
\text { with the risk of } \\
\text { stunting in } \\
\text { Nganjuk }\end{array}$ & $\begin{array}{l}225 \text { children } \\
\text { under five year } \\
\text { of age }\end{array}$ & $\begin{array}{l}\text { an analytic } \\
\text { observational } \\
\text { study with a case } \\
\text { control design }\end{array}$ & $\begin{array}{l}\text { Nganjuk, east } \\
\text { Java Indonesia }\end{array}$ & $\begin{array}{l}\text { The risk of stunting } \\
\text { increases with maternal } \\
\text { height }<150 \mathrm{~cm} \text {, birth } \\
\text { length }<48 \mathrm{~cm} \text {, and } \\
\text { large family size. }\end{array}$ \\
\hline $\begin{array}{l}\text { Titaley et al. } \\
(2019)\end{array}$ & $\begin{array}{l}\text { To examine } \\
\text { the } \\
\text { determinants } \\
\text { of stunting in } \\
\text { children aged } \\
0-2 \text { years In } \\
\text { Indonesia } \\
\text { using adata } \\
\text { derived }\end{array}$ & 24,657 & $\begin{array}{l}\text { Basic } \\
\text { survey }\end{array}$ & $\begin{array}{l}33 \text { provinces in } \\
\text { Indonesia }\end{array}$ & $\begin{array}{l}\text { There are } 20 \text { potensial } \\
\text { predictors of stunting } \\
\text { that categorized into } \\
\text { four main gropus ie., } \\
\text { household and housing } \\
\text { (maternal and paternal } \\
\text { characteristics, } \\
\text { antenatal care serices } \\
\text { and child characteristic }\end{array}$ \\
\hline
\end{tabular}

\section{Discussion}

Childhood stunting is a kind of malnutrition in children that potentially give negative impact to children's growth and development, quality of life and future life of the stunting children. Stunting is considered to be a major public health problem in Indonesia as in other developing countries. Despite having several interventions such as specific and sensitive intervention approaches, the prevalence of stunting in Indonesia among children under five year of age is $31 \%$ still is higher than normal standardized WHO of $20 \%$. It shows that progress in reducing and managing childhood stunting has been slow over the past decade.

The author used the WHO conceptual framework in this review of the literature on predictors child stunting in Indonesia. This review identified a number of factors that have beed studied for the association with stunting in children under five year of age, namely as followed:

\subsection{Household and Family Factors}

Child Factors (Low birth weight, premature birth)

Low birth weight

Low birth weight (LBW) babies have a risk of morbidity such as delayed of growth and development of child. In this review the author found there are four studies indicated that low birth weight is a determinant of childhood stunting in Indonesia. Palino, Majid and Ainurafiq (2017) conducted study in Kendari found that low birth weight is a determinant of stunting with $\mathrm{OR}=5.5$, which means it has a 5.5 times greater risk of experiencing stunting compared to toddlers who have a history of LBW. This is supported by research by Murtini and Jamaludin (2018) in Rappang who found that there was a relationship of LBW with stunting with a value of $p=0.008$. In line research also conducted by Rukmana, Briawan and Ekayanti (2016) indicated that low birth weight $<2500$ grams is a risk factor for stunting with an OR value of 4.1 which means that children with LBW have a risk 4.1 times more likely to experience stunting. Similarly, Rahayuh et al. (2016) showed that there is a relationship between LBW and stunting with a value of $\mathrm{p}=0.029$. The impact of babies who have low birth weight will continue from generation to generation, children with LBW will have less anthropometric size on their development. Similar research conducted in Etiophia by Berhe et al. (2019), showed that LBW is predictor of stunting with an OR value of 5.3 which means that LBW has a 5.3 times greater risk of experiencing stunting. Other study in Madagascar found that LBW was more likely to experience stunting with an OR value of 1.6 (Rabaoarisoa et al., 2017). A study in Ghana carried out by Boah et al. (2019) indicated that LBW is a stunting determinant and 3 times more likely to have a risk of stunted growth. Prevention of LBW can be done by monitoring maternal health during pregnancy.

Result of this review identified that prematurity have been strongly associated with child stunting in Indonesia. As Prawirohartono, Nurdiati and Hakimi (2016) conducted a secondary analysis of data collected between 1995 to 
1999 and found that premature birth was associated with an RR of 7.11 (95\% CI [2.07, 24.48]). Low birth weight is a predicting factor to growth completion after birth. LBW is correlated to IUGR and or preterm delivery (Wu et al., 2004). Other earlier study (Karima et al., 2012) indicated that there is significant relationship between nutritional status of mother, weights gained during pregnancy, iron intake and the age of gestation with the incidence of LBW. A study in Zimbabwe showed that growth of the LBW babies are well behind the growth of normal weight babies and signifivant length differences were behind the growth of normal weight babies and significant length differences were seeming at 12 months of age (Mbuya et al., 2010). Babies with LBW under 2,500 grams have a higher risk of infection, malnutrition and other illness (WHO, 2010). Birth weight is an important and reliable indicator to determine the health, nutrition and socio- economic status of people in developed and developing countries (WHO, 2017; Aryastami et al., 2017).

Maternal factor

\section{Maternal or paternal short stature}

Short paternal stature was also a determinant factor for prevalence of child stunting (WHO., 2015). This review identified there are two studies found that there is association between paternal short stature with child stunting under five year of age. Oktarina and Sudiarti (2015) identified there is significant determinant factors of stunting among subjects $(\mathrm{p}<0.05)$ was mother's height $(\mathrm{OR}=1.36)$. Similarly, recent study by Manggala et al. (2018) found maternal height has correlated with growth failure in children and short parents seemed to have stunted children (Sinha et al., 2018). Other study by Indiani et al. (2018) indicated that short mother $<150 \mathrm{~cm}$ were more likely to have stunting than mother with normal height $(\geq 150 \mathrm{~cm})(\mathrm{b}=2.59 ; 95 \% \mathrm{CI}=-0.75$ to $4.42 ; \mathrm{p}=0.006)$. The result of this study supported a study of Aguayo et al. (2016), which stated that mothers who were $<145 \mathrm{~cm}$ tall would increase the incidence of stunting in infants by 2.04 times than mothers who were $\geq 145 \mathrm{~cm}(\mathrm{~b}=2.04 ; 95 \% \mathrm{CI}=1.46$ to 2.81). The association between maternal or parental stature and liner growth of children is might because of genetic factors, adequate nutritional intake and reproductive health of mothers (Sinha et al., 2018; Stewart et al., 2013).

\section{Maternal or paternal education}

Result of this review noticed there is association of low paternal education to child stunting. Six studies reported that parental education was a determinant factor of inadequate nutritional status of children which leading to stunted child (Manggala et al., 2018; Rachmi, Agho, Li \& Baur., 2016; Rukmana, Briawan \& Ekayanti., 2016; Ni’mah \&Nadhiroh., 2015; Rohmawati \& Antika., 2014; Mauludyani, Fahmida \& Santika, 2012). Other study conducted by Astari, Nasoetion and Dwiriani (2005) found that parent with having higher educational background may have better understanding of the need of adequate nutritional status, growth and development of a child, which may able to provide optimal care to their children. It is concurrent with WHO Conceptual Framework on Childhood Stunting that stated inadequate maternal care practice and poor maternal education as determinants of childhood stunting (Beal et al., 2017; Stewart et al., 2013).

\section{Family size}

Other significant factors of the household and family factor identified in this review was family size. Result of the review evidence found that there was an association between family size and child stunting. Two studies showed that there was an association between family size and stunting, and it was statistically significant (Oktarina \& Sudiarti, 2014) and Indriani et al. (2018). For instance, Indriani et al. (2018) indicated that there was a correlation between family size and stunting that there was an association between family size and stunting. This study showed it was significant statistically. Family size $\geq 5$ have possibility of stunting ( $b=2.31 ; 95 \% \mathrm{CI}=0.34$ to 4.29 ; $\mathrm{p}=0.022$ ). Similarly, a study conducted in Ethiopia by Wolde, Berhan and Chala (2015) found thathaving large family size ( $\mathrm{AOR}=3.3 ; 95 \% \mathrm{CI}, 1.4-7.9)$ would increase the incidence of child stunting. Children from big family size may less get nutrition intake, lack of parent attention and care (Proverawati \&Wati., 2011). Parents of large family size should spend more monet to fulfill their family needs.

\subsection{Infection}

Based on the WHO framework infection includes enteric infection (diarrheal disease, environmental enteropathy, and helminths), respiratory infections, malaria, and inflammation. Literature notes that respiratory and enteric infection is predictor of child stunting (Beal et al., 2017). In our review infection is one of predictor of stunting in children under of five years of age. Two studies found that there is a relationship between infectious diseases and the incidence of stunting (Kusumawati, Rahardjo \& Sari., 2015; Priyono, Sulistiyani \& Ratnawati., 2015). This is supported by Syabandini et al. (2018) which found that children who have a history of infection are 9 times greater risk of stunting compared to children without a history of infection with $\mathrm{p}=0.001$. A similar study was also 
conducted by Maywita (2018) in Lubuk Begalung who found that there was a significant relationship between the history of infectious disease and the incidence of stunting with an OR value of 3,868 . It means that it has a risk of 3.868 times greater for stunting than children without a history of infectious disease.

Exposure to infectious diseases has a more severe effect of growth faltering in normal children. Another study supporting by Aridiyah et al. (2015) in Lumajang's rural and urban areas which found factors that influence stunting in children under five year of age in rural areas and urban is a history of infectious diseases. Kusumawati, Rahardjo and Sari et al. (2015) showed that risk factors and became the most dominant factor is infectious disease. The recent study conducted by Berhe (2019) in Etiophia and Rabaoarisoa et al. (2017) in Madagascar also found diarrhea is a risk factor for stunting $(\mathrm{OR}=5.3)$, which means it has a 5.3 times greater risk of experiencing stunting and trichuristrichiura infection $(2,4 ; 95 \%)$ is the main stunting factor. Prevention of infection can be done by avoiding the originator of the infection and handling appropriately and immediately if an infection has occurred.

\subsection{Breasfeeding}

According the WHO framework under unoptimal breastfeeding practices, includes delayed initiation of breastfeeding, unexlusive breastfeeding, and early termination of breastfeeding. Breast milk is known as essential feeding for infants during the first six months of life. The World Health Organization and Indonesian Ministry of Health recommend all babies must be given full exclusive breastfeeding. It is needed for babbies to enhancing growth and development of infants (Martin et al., 2011). Results of this review found that there are three studies identified unexclusive breastfeeding had an association of child stunting (Manggala et al., 2018; Ni'mah \& Nadhiroh., 2015; Romawati \& Antika., 2014). The WHO framework states that unexlusive breastfeeding practices, delayed initiation of breastfeeding, and early termination of breastfeeding are significantly associated with childhood stunting

\section{Conclusions and Reccomendations}

The results of this review show that there is a diverse range of predictors of stunting in children under five years of age in Indonesia. The current evidence in Indonesia mainly align with the common of proximate factors that found in a broad of literature such low birth weight, premature birth, parental short stature, parental education, family size, infection, and breastfeeding that significantly associated with childhood stunting. Not all of proximate risk factors identified in the WHO framework has been examined for the prevalence of stunting in Indonesia. It is therefore needed future studies to addressing these knowledge gaps in Indonesia. The findings indicate that the need for developing integrated health promotion, prevention and interventions to reduce stunting in Indonesia. Intergative stunting prevention and interventions should use multi sectoral approaches that involve health care professionals, families, government and communities.

\section{Acknowledgments}

I would like to express our gratitude to Universitas Padjadjaran Indonesia for providing grant research (RKDU)

\section{Competing Interests Statement}

The author declares that she has no competing interests.

\section{References}

Addo, O. Y., Stein, A. D., Fall, C. H., Gigante, D. P., Guntupalli, A. M., Horta, B. L., ... \& Richter, L. M. (2013). Maternal height and child growth patterns. The Journal of pediatrics, 163(2), 549-554. https://doi.org/10.1016/j.jpeds.2013.02.002

Aryastami, N. K., Shankar, A., Kusumawardani, N., Besral, B., Jahari, A. B., \& Achadi, E. (2017). Low birth weight was the most dominant predictor associated with stunting among children aged 12-23 months in Indonesia. BMC Nutrition, 3(1), 16. https://doi.org/10.1186/s40795-017-0130-x

Aridiyah, F. O., Rohmawati, N., \& Ririanty, M. (2015). Faktor-faktor yang Mempengaruhi Kejadian Stunting pada Anak Balita di Wilayah Pedesaan dan Perkotaan (The Factors Affecting Stunting on Toddlers in Rural and Urban Areas). Pustaka Kesehatan, 3(1), 163-170.

Beal, T., Tumilowicz, A., Sutrisna, Izwardy, D., \& Neufeld, L. M. (2018). A review of child stunting determinants in Indonesia. Maternal \& child nutrition, 14(4), e12617. https://doi.org/10.1111/mcn.12617

Berhe, K., Seid, O., Gebremariam, Y., Berhe, A., \& Etsay, N. (2019). Risk factors of stunting (chronic undernutrition) of children aged 6 to 24 months in Mekelle City, Tigray Region, North Ethiopia: An unmatched case-control study. PloS one, 14(6). https://doi.org/10.1371/journal.pone.0217736

Black, R. E., Victora, C. G., Walker, S. P., Bhutta, Z. A., Christian, P., De Onis, M., ... \& Uauy, R. (2013). Maternal 
and child undernutrition and overweight in low-income and middle-income countries. The lancet, 382(9890), 427-451. https://doi.org/10.1016/S0140-6736(13)60937-X

Black, R. E., Allen, L. H., Bhutta, Z. A., Caulfield, L. E., De Onis, M., Ezzati, M., ... \& Maternal and Child Undernutrition Study Group. (2008). Maternal and child undernutrition: global and regional exposures and health consequences. The lancet, 371(9608), 243-260. https://doi.org/10.1016/S0140-6736(07)61690-0

Boah, M., Azupogo, F., Amporfro, D. A., \& Abada, L. A. (2019). The epidemiology of undernutrition and its determinants in children under five years in Ghana. PloS one, 14(7). https://doi.org/10.1371/journal.pone.0219665

De Onis, M., Blössner, M., \& Borghi, E. (2012). Prevalence and trends of stunting among pre-school children, 1990-2020. Public health nutrition, 15(1), 142-148. https://doi.org/10.1017/S1368980011001315

Indriani, D., Dewi, Y. L. R., Murti, B., \& Qadrijati, I. (2018). Prenatal factors associated with the risk of stunting: a multilevel analysis evidence from Nganjuk, East Java. Journal of Maternal and Child Health, 3(4), 294-300. https://doi.org/10.26911/thejmch.2018.03.04.07

Karima, K., \& Achadi, E. L. (2012). Maternal nutritional status and baby's weight at birth. National Public Health Journal, 7(3), 111-1. https://doi.org/10.21109/kesmas.v7i3.57

Kusumawati, E., Rahardjo, S., \& Sari, H., P. (2015). Stunting Risk Management Model for Children Under Three Years. National Journal of Public Health, 9(3), February. https://doi.org/10.21109/kesmas.v9i3.572

Manggala, A. K., Kenwa, K. W. M., Kenwa, M. M. L., Jaya, A. A. G. D. P., \& Sawitri, A. A. S. (2018). Risk factors of stunting in children aged 24-59 months. Paediatrica Indonesiana, 58(5), 205-12. https://doi.org/10.14238/pi58.5.2018.205-12

Martins, V. J., Toledo Florêncio, T. M., Grillo, L. P., Do Carmo, P. F., Martins, P. A., Clemente, A. P. G., ... \& Sawaya, A. L. (2011). Long-lasting effects of undernutrition. International journal of environmental research and public health, 8(6), 1817-1846. https://doi.org/10.3390/ijerph8061817

Mauludyani, A. V. R., Fahmida, U., \& Santika, O. (2012). Undernutrition Prevalence Among Children Under Two Years Old In Indonesia During Economic Crisis And Its Related Factors. Jurnal Gizi dan Pangan, 7(3), 169-174. https://doi.org/10.25182/jgp.2012.7.3.169-174

Maywita, E. (2018). Faktor Risiko Penyebab Terjadinya Stunting Pada Balita Umur 12-59 Bulan Di Kelurahan Kampung Baru Kec. Lubuk Begalung Tahun 2015. Jurnal Riset Hesti Medan Akper Kesdam I/BB Medan, 3(1), 56-65. https://doi.org/10.34008/jurhesti.v3i1.24

Mbuya, M., Chideme, M., Chasekwa, B., \& Mishra, V. (2010). Biological, Social, and Environmental Determinants of Low Birth Weight and Stunting among Infants and Young Children in Zimbabwe, in Zimbabwe working paper No. 7. Calverton: ICF Macro p. 39.

Meilyasari, F., \& Isnawati, M (2014). Faktor Resiko Kejadian Stunting pada Balita Usia 12 Bulan di Desa Purwokerto Kecamatan Patebon, Kabupaten Kendal. Journal of Nutrition College, 3(2), 303-309. https://doi.org/10.14710/jnc.v3i2.5437

Murtini, \& Jamaluddin. (2018). Factors Related to Stunting in Children 0 - 36 Months. Enlightenment Scientific Journal, 7(2), December.

Nadhiroh, S. R., \& Ni'mah, K. (2015). Factors related to the incidence of stunting in infants, 13-19. Indonesian Nutrition Media, 10, January 1-June, 13-19

National Institute of Health Research and Development, Republic of Indonesia. (2018). Basic Health Research 2018: National Report 2018. National Institute of Health Research and Development, Ministry of Health, Republic of Indonesia: Jakarta, Indonesia.

National Institute of Health Research and Development, Republic of Indonesia. (2013) Basic Health Research 2013: National Report 2013. National Institute of Health Research and Development, Ministry of Health, Republic of Indonesia: Jakarta, Indonesia.

Ni'mah, K., \& Nadhiroh, S. R. (2015). Faktor yang berhubungan dengan kejadian stunting pada balita. Media Gizi Indonesia, 10(1), 13-19. http://dx.doi.org/10.20473/mgi.v10i1.13-19

Oktarina, Z., \& Sudiarti, T. (2014). Faktor risiko stunting pada balita (24-59 bulan) di Sumatera. Journal Gizi Dan Pangan, 8, 175-80. https://doi.org/10.25182/jgp.2013.8.3.177-180

Palino, I. L., Majid, R., \& Ainurafiq. (2017). Determinants of Stunting Events in Toddlers Age 12-59 Months in 
the Work Area of Puuwatu Health Center, Kendari City 2016. 2016. Scientific Journal of Public Health Students, 2(6).

Phalkey, R. K., Aranda-Jan, C., Marx, S., et al. (2015). Systematic review of current efforts to quantify the impacts of climate change on undernutrition. Proc Natl Acad Sci USA, 112(33), E4522-4529. https://doi.org/10.1073/pnas.1409769112

Priyono, D. I. P., Sulistiyani, \& Ratnawati, L. Y. (2015). Determinants of Stunting Events in Children Aged 12-36 Months in the Working Area of Randuagung Health Center, Lumajang Regency. e-Journal of Health Reader, $3(2)$.

Proverawati, A., \&Wati, E. K., (2011). Ilmu gizi untuk keperawatan \& gizi kesehatan. Yogyakarta: Nuha Medika

Rachmi, C. N., Agho, K. E., Li, M., \& Baur, L. A. (2016). Stunting, Underweight and Overweight in Children Aged 2.0-4.9 Years in Indonesia: Prevalence Trends and Associated Risk Factors. PloS one, 11(5), e0154756. https://doi.org/10.1371/journal.pone.0154756

Rahayuh, A., Yulidasari, F., Putri, A., O., Rahman F., \& Rosadi, D. (2016). Risk Factors Associated with Short Events in Children Age 6-24 Months. Journal of Public Health, 11(2), 96-10.

Rohmawati, N., \&Antika, R. B. (2017). Risk Factors Stunting Incidence in Children Aged 6-36 months in Jember Regency. Proceeding the 3rd International Nursing Conference Faculty of Nursing Jember University.

Rabaoarisoa, C. R., Rakotoarison, R., Rakotonirainy, N. H., Mangahasimbola, R. T., Randrianarisoa, A. B., Jambou, R., ... \& Randremanana, R. V. (2017). The importance of public health, poverty reduction programs and women's empowerment in the reduction of child stunting in rural areas of Moramanga and Morondava, Madagascar. PloS one, 12(10). https://doi.org/10.1371/journal.pone.0186493

Rukmana, E., Briawan, D., \& Ekayanti, I. (2016). Risk factors for stunting in children aged 6-24 months in the city of Bogor. MKMI Journal, 12(3), September.

Sari, M., Dee, S. D., Bloem, M. W., Sun, K., Thorm, L., \& Moench, P. R. (2010). Higher household expenditure on animal source and nograim foods lowers the risk of stunting among children 0-59 months old in Indonesia. Implications of rising food prices. The Journal of Nutrition, 140, 196-200. https://doi.org/10.3945/jn.109.110858

Shine, S., Tadesse, F., Shiferaw, Z., Mideksa, L., \& Seifu, W. (2017). Prevalence and associated factors of stunting among 6-59 months Children in Pastoral Community of Korahay Zone, Somali Regional State, Ethiopia 2016. Journal of Nutritional Disorders and Therapy, 7(1), 208. https://doi.org/10.4172/2161-0509.1000208

Sinha, B., Taneja, S., Chowdhury, R., Mazumder, S., Rongsen-Chandola, T., Upadhyay, R. P., ... \& Bhan, M. K. (2018). Low-birthweight infants born to short-stature mothers are at additional risk of stunting and poor growth velocity: Evidence from secondary data analyses. Maternal \& child nutrition, 14(1), e12504. https://doi.org/10.1111/mcn.12504

Stewart, C. P., Iannotti, L., Dewey, K. G., Michaelsen, K. F., \& Onyango, A. W. (2013). Contextualising complementary feeding in a broader framework for stunting prevention. Maternal \& child nutrition, 9, 27-45. https://doi.org/10.1111/men.12088

Syabandini, I. P., Pradigdo, S. F., Suyatno, \& Pangestuti, D. R. (2018). Risk Factors for Stunting in Children 6-24 Months in Fishermen Areas. Journal of Public Health, 6(1).

Titaley, C. R., Ariawan, I., Hapsari, D., Muasyaroh, A., \& Dibley, M. J. (2019). Determinants of the Stunting of Children Under Two Years Old in Indonesia: A Multilevel Analysis of the 2013 Indonesia Basic Health Survey. Nutrients, 11(5), 1106. https://doi.org/10.3390/nu11051106

The Global Nutritional Report (2017). Nourishing the SDGs, https://globalnutritionreport.org/reports/2017-global-nutrition-report/

Torlesse, H., Cronin, A. A., Sebayang, S. K., \& Nandy, R. (2016). Determinants of stunting in Indonesian children: Evidence from a cross-sectional survey indicate a prominent role for the water, sanitation and hygiene sector in stunting reduction. BMC Public Health, 16, 669. https://doi.org/10.1186/s12889-016-3339-8

UNICEF. (2014). Undernutrition contributes to half of all deaths in children under 5 and is widespread in Asia and Africa. Retrieved December 31, 2014, from http://data.unicef.org/nutrition/malnu- trition

Uauy, R., Kain, J., \& Corvalan, C. (2011). How can the Devel- opmental Origins of Health and Disease (DOHaD) hypothesis contribute to improving health in devel- oping countries? The American Journal of Clinical 
Nutrition, 94(60). https://doi.org/10.3945/ajen.110.000562

Wolde, M., Berhan, Y., \& Chala, A. (2015). Determinants of underweight, stunting and wasting among schoolchildren. BMC public health, 15, 8. https://doi.org/10.1186/s12889-014-1337-2

World Health Organization [WHO]. (2015). Child growth standards: length/height-for-age. Geneva: World Health Organization. Retrieved from http://www.who.int/childgrowth/standards/ height_for_age/en/.

World Health Organization [WHO]. (2015). Child growth indicators and their interpretation. http://www.who.int/ nutgrowthdb/about/introduction/en/index2.html Published n.d.

World Health Organization [WHO]. (2014). Global Nutrition Targets 2025. Stunting Policy Brief, 14(3).

World Health Organization [WHO]. (2012). Maternal, infant and young child nutrition. (WHO, Ed.). Geneva, Switzerland: The sixty-fifth world health assembly WHA65.6

World Health Organization [WHO]. (2010). Nutrition landscape information system (NLIS) country profile indicators interpretation guide. Switzerland: WHO press.

\section{Copyrights}

Copyright for this article is retained by the author(s), with first publication rights granted to the journal.

This is an open-access article distributed under the terms and conditions of the Creative Commons Attribution license (http://creativecommons.org/licenses/by/4.0/). 